\author{
Т. С. Жулай ${ }^{1,2}$, І. А. Зупанець ${ }^{1}$, С. К. Шебеко ${ }^{1}$, Н. П. Безугла ${ }^{1}$, С. М. Зімін ${ }^{1}$ \\ НАЦІОНАЛЬНИЙ ФАРМАЦЕВТИЧНИЙ УНІВЕРСИТЕТ ${ }^{1}$, ХАРКІВ \\ КОМУНАЛЬНЕ НЕКОМЕРЦІЙНЕ ПІДПРИЕМСТВО "МІСЬКА КЛІНІЧНА ЛІКАРНЯ № 30" \\ ХАРКІВСЬКОÏ МІСЬКОÏ РАДИ
}

\title{
ЕФЕКТИВНІСТЬ І ПЕРЕНОСИМІСТЬ ЕНІСАМІУМУ ЙОДИДУ НАЗАЛЬНОГО СПРЕЮ: РЕЗУЛЬТАТИ ДОКЛІНІЧНИХ ТА КЛІНІЧНИХ ДОСЛІДЖЕНЬ
}

Вступ. Існують відмінності в підходах до лікування гострого риносинуситу залежно від його провідних клінічних симптомів, зокрема назальної обструкції та лицьового болю. На АT “Фармак” (Україна) було розроблено новий назальний спрей з водним розчином Енісаміуму Йодиду (ЕнЙ) - оригінальну лікарську форму відомої фрармацевтичної речовини.

Мета дослідження-визначити ефрективність Енісаміуму Йодиду при лікуванні гострого риносинуситу і його переносимість/безпеку.

Методи дослідження. Об'єктом дослідження став ЕнЙ (назальний спрей) 10 мг/мл. Як рефрерентний препарат в експериментальній частині роботи було використано BNO-101 під торговою назвою "Sinupret ${ }^{\circledR}$ ". Експериментальний риносинусит відтворено на 24-х кролях (4 дослідні групи по 6 кролів у кожній) у 1-й день дослідження. 3 15-ї доби тварини отримували протягом 10-ти діб препарати: 0,9 \% фрізіологічний розчин (0,1 мл інтраназально) -у групах інтактного контролю та контрольної патології (1-й і 2-й групах відповідно), ЕнЙ (назальний спрей) (0,1 мл інтраназально) - у 3-й групі та BNO-101 (25 ма/мл інтрагастрально) у 4-й групі. Оцінювали результати лікування на 25-ту добу (лабораторне спостереження, результати аналізу перифреричної крові). Клінічну частину роботи проведено у вигляді одноцентрового, рандомізованого, подвійного сліпого, плацебо-контрольованого клінічного дослідження з ескалацією дози -вивчення локальної переносимості та безпеки (I фраза) різних доз нового лікарського препарату Енй (назального спрею) 10 мг/мл за участю здорових добровольців.

Результати й обговорення. На тлі розвитку експериментального риносинуситу за рахунок місцевої дії ЕнЙ (назальний спрей) достовірно позитивно впливав на перебіг патології. Аналіз статистичних даних локальної переносимості свідчить про те, що він не поступався плацебо за показниками "локальна переносимість" та “безпека", а всі встановлені відмінності були статистично незначущими.

Висновки. Отримані результати доклінічного дослідження показали, що, за даними лабораторних спостережень та гематологічних аналізів, Енісаміум Йодид чинить позитивний вплив на перебіг експериментального риносинуситу і при цьому за рівнем активності не поступається препарату порівняння BNO-101. Аналіз статистичних даних клінічного дослідження свідчить про добру переносимість/ безпеку використання Енісаміуму Йодиду (назального спрею) 10 мг/мл.

КЛЮЧОВІ СЛОВА: експериментальний риносинусит; Енісаміум Йодид (назальний спрей); клінічне дослідження; переносимість; безпека.

ВСТУП. Гострий риносинусит (ГРС) є топічним проявом респіраторної інфекції, найчастіше зумовленої вірусами (риновірусами, респіраторно-синцитіальними вірусами, аденовірусами та ін.), проте надзвичайно швидко запускається патогенетичний каскад запалення [1]. Таким чином, гострий вірусний риносинусит швидко трансформується в гострий післявірусний риносинусит, частина 3 яких лише в 0,5-2,0 \% дорослих та 5-13\% дітей може бути ускладнена приєднанням бактеріальної інфекції. Тоді йдеться про гострий бактеріальний риносинусит.

(c) Т. С. Жулай, І. А. Зупанець, С. К. Шебеко, Н. П. Безугла, С. М. Зімін, 2020.
Гострий риносинусит є однією з найпоширеніших патологій ЛОР-органів й уражає приблизно 12 \% населення [1]. Крім того, гострий риносинусит це дуже поширений діагноз, який становить приблизно 30 млн випадків первинної медичної допомоги в США і вимагає понад 11 млрд доларів витрат на охорону здоров'я щорічно [2]. Незважаючи на високу поширеність та економічний вплив ГРС, існують значні відмінності в підходах до лікування пацієнтів із цим захворюванням залежно від провідних клінічних симптомів, зокрема назальної обструкції та лицьового болю.

Своєчасна діагностика і раціональна терапія ГРС регламентованіEPOS 2020[3]йУнісікованим 
клінічним протоколом первинної, вторинної (спеціалізованої) та третинної (високоспеціалізованої) медичної допомоги: гострий риносинусит (наказ МО3 України від 11.02.2016 р. № 85) [4]. Аналізуючи цей протокол, можемо зробити висновок, що в ньому недостатньо представлено препарати для місцевої патогенетичної терапії різних фрорм ГРС, зокрема гострого вірусного риносинуситу і гострого післявірусного риносинуситу. Це пов'язано з відсутністю на фрармацевтичному ринку України лікарської фрорми препарату, який відповідав би всім вимогам до “ідеального” препарату для патогенетичного лікування ГРС:

- наявність топічної (інтраназальної) форми, що забезпечить простоту застосування, вищу ефективність та безпечність для швидкого купірування локальних симптомів ГРС;

- різноманіття фармакологічнихвластивостей 3 урахуванням етіології і патогенезу ГРС (протизапальні, аналгетичні властивості, противірусна та інтерфероногенна активність).

На АТ "Фармак" (Україна) було розроблено новий назальний спрей з водним розчином Енісаміуму Йодиду (ЕнЙ) (N-benzyl-1-methylpyridin1-ium-4-carboxamide iodide) - оригінальну лікарську фрорму відомої фрармацевтичної речовини.

Доцільність розробки нової лікарської фрорми ЕнЙ підтвердили результати багатьох доклінічних досліджень. Виражену протизапальну дію Енй було доведено в [5-7], що виправдовує потенційно високу його ефективність у лікарській формі “назальний спрей” для лікування ГРС наявність прямого позитивного впливу на запалення і набряк слизової оболонки в порожнині носа, придаткових пазух носа та співустя.

Відповідно до вказівок, викладених у ряді документів Міністерства охорони здоров'я України [8-10] і міжнародних регламентуючих документах [11-16], при розробці нового лікарського препарату перш за все необхідно провести клінічне дослідження з оцінки переносимості/ безпеки за участю здорових добровольців.

Вивчення ефрективності ЕнЙ при лікуванні визначеного патологічного стану в лабораторних тварин і безпеки його застосування (в здорових добровольців у рамках проведення I фрази клінічного випробування) стали метою доклінічних та клінічного досліджень.

МЕТОДИ ДОСЛІДЖЕННЯ. Дослідження ефективності нового назального спрею Енісаміум Йодид (АТ "Фармак", Україна) 3 концентрацією активної речовини 10 мг/мл було проведено в рамках доклінічної частини роботи з поглибленого вивчення фрармакологічних властивостей ЕнЙ на різних моделях експериментального риносинуситу (ЕРC). Концентрацію активної речовини об'єкта дослідження обрали з урахуванням результатів попередніх етапів доклінічних досліджень, які продемонстрували яскраво виражену протизапальну та знеболювальну дію [5-7].

Як референтний препарат було використано BNO-101 під торговою назвою "Sinupret $₫$ " ("Bionorica SE”, Німеччина) - таблетки, вкриті оболонкою для перорального застосування, в кожній таблетці міститься 78 мг натурального трав'яного екстракту (Gentianae radix, Primulae flos, Rumicis herba, Sambuci flos i Verbenae трава у співвідношенні 1:3:3:3:3) [17].

Для відтворення ЕРС у цьому дослідженні було використано 24 кролі породи сірий Велетень обох статей віком 90-110 днів масою 2,5-3,0 кг. Розподіл експериментальних тварин по групах показано в таблиці 1. У ході дослідження тварин зважували, розподіляли по групах та поміщали в окремі клітки. Проводили лабораторне спостереження за тваринами - за їх масою тіла, споживанням їжі та води, поведінкою, а також клінічними проявами ГРС. Іммобілізацію кролів на всіх етапах дослідження здійснювали за допомогою спеціального фріксувального бокса. Базові дані, що стосуються всіх досліджуваних груп, наведено в таблиці 1.

Експериментальних тварин утримували у Навчально-науковому тренінговому центрі медико-біологічних досліджень Національного фрармацевтичного університету, дотримуючись санітарних норм та необхідного раціону. Всі до-

Таблиця 1 - Розподіл експериментальних тварин (*n=24)

\begin{tabular}{|c|c|c|c|c|}
\hline \multicolumn{2}{|r|}{$\begin{array}{l}\text { Експериментальна } \\
\text { група }\end{array}$} & Досліджуваний об'єкт & Доза & $\begin{array}{c}\text { Спосіб } \\
\text { введення }\end{array}$ \\
\hline 1-ша & Група інтактного контролю (**n=6) & 0,9 \% фрізіологічний розчин & $0,1 \mathrm{мл}$ & Інтраназально \\
\hline 2-га & Група контрольної патології (*夫n=6) & 0,9 \% фрізіологічний розчин & 0,1 мл & Інтраназально \\
\hline 3-тя & $\begin{array}{l}\text { Група тварин, яких лікують } \\
\text { Енісаміумом Йодидом }\left({ }^{\star *} \mathrm{n}=6\right)\end{array}$ & $\begin{array}{c}\text { Енісаміум Йодид } \\
\text { (назальний спрей) } 10 \text { мг/мл }\end{array}$ & 0,1 мл & Інтраназально \\
\hline 4-та & $\begin{array}{l}\text { Група тварин, яких лікують } \\
\text { BNO-101 (**n=6) }\end{array}$ & $\begin{array}{c}\text { BNO-101 } \\
\text { (таблетки, вкриті оболонкою) }\end{array}$ & $25 \mathrm{Mг} / \mathrm{K}^{\mathrm{a}}$ & Інтрагастрально \\
\hline
\end{tabular}

Примітки:

1. *n - загальна кількість експериментальних тварин; **n - кількість експериментальних тварин у кожній групі.

2. ${ }^{a}-\mathrm{ED}_{50}$ за протизапальною активністю. 
слідження було виконано відповідно до загальних етичних принципів проведення експериментів на тваринах, встановлених Директивою 2010/63/ $€ С$ щодо захисту тварин, що використовуються для експериментальних та інших наукових цілей [18]. Дизайн дослідження затвердила Комісія 3 біоетики Національного фрармацевтичного університету (Харків, Україна) (протокол № 3 від 15 березня 2017 р.).

Енісаміум Йодид (назальний спрей) 10 мг/мл було запропоновано використовувати в дозі 0,1 мл на одну тварину інтраназально, що відповідає дозі 0,03 мл/кг з урахуванням середньої маси кроля на початок дослідження (приблизно 3,0 кг). Відповідно до рекомендацій FDA щодо екстраполяції дози [19], ця доза відповідає 0,6 мл для людини, тобто 0,2 мл (подвійне натискання на дозувальний клапан) 3 рази на день. Енісаміум Йодид (назальний спрей) 10 мг/мл вводили в незміненому стані в правий носовий хід кроля за допомогою піпетки фріксованого об'єму Biohit Proline 200 мкл [20]. У групах інтактного контролю та контрольної патології використовували 0,9% фрізіологічний розчин в еквівалентній дозі (спосіб введення такий самий).

За рекомендаціями FDA [19], BNO-101 застосовували в дозі 25 мг/кг, що відповідає дозі 480 мг для людини або 6 таблеткам на добу, тобто 2 таблетки 3 рази на день, що дорівнює рекомендованому режиму дозування, зазначеному в інструкції до препарату [17]. Вводили його кролям перорально у вигляді водної суспензії за допомогою спеціального катетера 3 еластичною канюлею [20].

Експериментальний риносинусит у кролів був індукований у 1-й день дослідження шляхом тампонади правої половини носової порожнини під загальною анестезією (кетамін/ксилазин 35/5 мг/кг, внутрішньом'язово) [21], що є добре відомою моделлю риносинуситу (РС) в експериментальній ринології $[22,23]$. Через 15 діб після відтворення патології у кролів вилучали тампони та проводили контроль наявності РС за допомогою назальної ендоскопії [24-26]. Також здійснювали забір крові з вушної вени і вивчали гематологічні показники стандартними лабораторними методами [27-29]. При цьому в крові визначали вміст гемоглобіну, еритроцитів, лейкоцитів, розраховували кольоровий показник (КП), визначали лейкоцитарну формулу та швидкість осідання еритроцитів (ШОЕ).

Починаючи з 15-ї доби і протягом наступних 10-ти діб тваринам вводили 0,9 \% фрізіологічний розчин, ЕнЙ (назальний спрей) 10 мг/мл та BNO-101 у відповідних дозах (табл. 1). Наприкінці дослідження (на 25-ту добу) після оцінки результатів лікування (виконання назальної ендоскопії та аналізу крові також, як і на 15-ту добу) здійснювали евтаназію тварин під загальною анестезією відповідно до біоетичних стандартів проведення експериментів на лабораторних тваринах [30].

Безпеку ЕнЙ (назального спрею) досліджували в рамках проведення одноцентрового, рандомізованого, подвійного сліпого, плацебоконтрольованого клінічного дослідження 3 ескалацією дози в Клініко-діагностичному центрі Національного фрармацевтичного університету. Метою цього дослідження була оцінка локальної переносимості й безпеки різних доз лікарського препарату "Енісаміум Йодид, спрей назальний 10 мг/мл по 10 мл у фрлаконі" (виробництва АТ “Фармак", Україна) за участю здорових добровольців при наростанні рівнів дозування. У дослідженні брали участь 27 здорових добровольців обох статей віком від 18 до 50 років, поділених на три групи 3 різними режимами дозування досліджуваного лікарського засобу (ДЛЗ)/плацебо (одноразово 1 доза, одноразово 2 дози і 2 дози 3 рази на день). Рішення щодо ескалації дози приймав Комітет моніторингу безпеки даних після оцінки даних по кожному режиму дозування. Оцінка локальної переносимості та безпеки ДЛЗ/плацебо ґрунтувалась на результатах риноскопії (табл. 2), оцінки суб'єктивних відчуттів (присмак, відчуття дискомфрорту та ін.) після введення досліджуваного лікарського препарату або плацебо, а також реєстрації побічних реакцій (ПР)/побічних явищ, даних фрізикального огляду, результатах

Таблиця 2 - Бальна оцінка даних риноскопії

\begin{tabular}{|c|c|c|c|c|}
\hline \multirow{2}{*}{$\begin{array}{l}\text { Об'єктивний } \\
\text { симптом }\end{array}$} & \multicolumn{4}{|c|}{ Бал } \\
\hline & 0 & 1 & 2 & 3 \\
\hline Набряк & Відсутній & Незначний & Помірно виражений & Виражений \\
\hline Гіперемія & Відсутня & Незначна & Помірна & Виражена \\
\hline $\begin{array}{l}\text { Наявність } \\
\text { виділень }\end{array}$ & $\begin{array}{l}\text { В межах } \\
\text { норми }\end{array}$ & $\begin{array}{c}\text { Незначне збільшення } \\
\text { виділень/незначна сухість }\end{array}$ & $\begin{array}{c}\text { Помірне збільшення } \\
\text { виділень/помірна сухість }\end{array}$ & $\begin{array}{l}\text { Рясне виділення/ } \\
\text { виражена сухість }\end{array}$ \\
\hline $\begin{array}{l}\text { Характер } \\
\text { виділень }\end{array}$ & Слизисті & Водянисті & Водянисто-геморагічні & $\begin{array}{l}\text { Геморагічні } \\
\text { або гнійні }\end{array}$ \\
\hline Носове дихання & Не порушене & Незначно порушене & Помірно порушене & Відсутнє \\
\hline
\end{tabular}

Примітка. ${ }^{1}$ - Дослідник оцінював усі відхилення від норми (1 бал і більше) як “Клінічно значуще” або “Клінічно незначуще”. 
лабораторно-інструментальних обстежень тощо.

Клінічне дослідження було проведено відповідно до чинного законодавства України, етичних принципів Гельсінської декларації, діючих нормативних вимог, з дотриманням принципів Належної клінічної практики (GCP) $[12,31,32]$, а також згідно із затвердженим протоколом клінічного випробування.

Статистичний аналіз отриманих результатів доклінічного дослідження проводили за допомогою одностороннього дисперсійного аналізу Краскела - Уолліса та U-критерію Манна - Уїтні для апостеріорних парних порівнянь [33, 34] з використанням комп'ютерного програмного забезпечення IBM SPSS Statistics v. 22 (IBM Corp., США) та MS Excel 2016 (Microsoft Corp., США). Рівнем статистичної значущості вважали $p<0,05$.

Статистичний аналіз отриманих результатів клінічного дослідження проводили для кожної з трьох груп із застосуванням методів описової статистики (медіана, стандартне відхилення, мінімальне і максимальне значення, довірчий інтервал, n) для показника "локальна переносимість"; порівнянням середніх оцінок показників “локальної переносимості" за допомогою критерію Манна - Уїтні та непараметричного методу Фрідмена [33, 34], а також попарним порівнянням у підгрупах з використанням непараметричного тесту Вілкоксона та поправки Бонферроні [10, 35]. Рівнем статистичної значущості вважали $p<0,05$.

РЕЗУЛЬТАТИЙ ОБГОВОРЕННЯ. ДОКЛінічНе дослідження. Лабораторні спостереження за тваринами показали, що вже через 1-2 доби після відтворення патології у кролів спостерігали перші ознаки РС - ускладнення носового дихання, появу шумів при цьому та розвиток кон'юнктивіту в правому оці (з боку носового ходу, який був затампонований). У подальшому з'являлись незначні слизисті виділення, ще більше посилювались ознаки кон'юнктивіту та виділення $з$ ока на правій стороні, під оком випадало волосся. Крім того, на правій стороні носа, вздовж носового ходу виникала припухлість, що в деяких кролів поширювалась під праве око. При надавлюванні на неї тварини проявляли больову поведінку, що свідчило про розвиток індукованого болю. 3 часом у кролів перекошувалась голова на праву сторону, тобто в бік ушкодження, що вказувало на наявність спонтанної больової реакції. При цьому рухова активність тварин та апетит знижувались. Після вилучення тампонів загальний стан кролів групи контрольної патології покращувався, але ознаки запалення порожнини носа не зменшувались. Також, як і раніше, спостерігали ускладнення дихання, ознаки кон'юнктивіту, припухлість з боку ушкодженого носового ходу та з'являлись рясні густі виділення з нього. На відміну від цього, у тварин, які починали отримувати досліджувані препарати, зовнішні ознаки патології через декілька діб зменшувались і далі практично повністю зникали.

У ході дослідження в кролів проводили забір та аналіз периферичної крові. При цьому основну увагу приділяли показникам, що відображають загальні ознаки запалення: вмісту лейкоцитів, лейкоцитарній фрормулі та ШОЕ. Отримані результати наведено в таблиці 3.

Результати, наведені в таблиці 3, свідчать про те, що у тварин групи контрольної патології станом на 15-ту добу розвитку РС спостерігали загальні ознаки запалення, на що вказували достовірний відносно групи інтактного контролю лейкоцитоз, зсув лейкоцитарної фрормули вліво та збільшення ШОЕ ( $<<0,05$, достовірно відносно інтактних тварин). При цьому вміст лейкоцитів у крові кролів підвищувався на 21,4 \%, вміст паличкоядерних нейтрофрілів - до 7,2 \% (проти 0,8 \% в інтактних тварин), сегментоядерних - до $31,5 \%$ (проти 22,7 \%), вміст лімороцитів, навпаки, знижувався до 56,9 \% (проти 71,7 \%), показник шОЕ зростав у 2,4 раза (3 4,0 до 9,5 мм/год). Інші гематологічні показники (вміст гемоглобіну, еритроцитів, КП) не змінювались та перебували в межах фрізіологічної норми для кролів [27-29]. Аналогічну картину крові в цей період спостережень було зафріксовано також і в кролів 3-ї та 4-ї груп ( $<<0,05$, достовірно відносно інтактних тварин), які в подальшому отримували ЕнЙ (назальний спрей) або BNO-101.

Під впливом інтраназального застосування ЕнЙ загальні ознаки запалення вірогідно знижувались ( $<<0,05$, достовірно відносно групи контрольної патології і стану тварин цієї групи на 15-ту добу дослідження). Так, на 25-ту добу дослідження достовірно відносно групи контрольної патології, а також стану до лікування (на 15-ту добу) вміст лейкоцитів зменшувався до інтактного рівня - 10,5×10\%, вміст паличкоядерних нейтрофрілів - до 1,8 \% (проти 5,9 \% у нелікованих тварин), сегментоядерних - до 24,6 \% (проти 29,6 \%). Вміст лімсоцитів при цьому, навпаки, збільшувався до 68,0 \% (проти 59,9 \%), що загалом вказувало на нормалізацію лейкоцитарної фрормули тварин. Показник ШОЕ також достовірно знижувався до інтактного рівня - в 1,9 раза (табл. 3). Отриманий результат свідчить про те, що на тлі розвитку ЕРС за рахунок місцевої дії протягом 10-ти діб ЕнЙ (назальний спрей) здатен достовірно впливати на 
Таблиця 3 - Вплив Енісаміуму Йодиду та BNO-101 на гематологічні показники кролів на тлі експериментального риносинуситу (*n=24)

\begin{tabular}{|c|c|c|c|c|}
\hline $\begin{array}{c}\text { Досліджуваний } \\
\text { показник }\end{array}$ & $\begin{array}{c}\text { Інтактний } \\
\text { контроль } \\
\left({ }^{* \star} n=6\right)\end{array}$ & $\begin{array}{c}\text { Контрольна } \\
\text { патологія } \\
\left({ }^{\star \star} \mathrm{n}=6\right)\end{array}$ & $\begin{array}{c}\text { Енісаміум Йодид } \\
\left({ }^{* *} n=6\right)\end{array}$ & $\begin{array}{c}\text { BNO-101 } \\
(* \star n=6)\end{array}$ \\
\hline \multicolumn{5}{|c|}{ 15-та доба дослідження } \\
\hline Гемоглобін, г/л & $129,60 \pm 5,10$ & $132,60 \pm 5,20$ & $131,40 \pm 5,20$ & $129,90 \pm 5,10$ \\
\hline Еритроцити, 10²/л & $4,60 \pm 0,16$ & $4,71 \pm 0,17$ & $4,57 \pm 0,17$ & $4,54 \pm 0,15$ \\
\hline КП & $0,85 \pm 0,04$ & $0,85 \pm 0,04$ & $0,87 \pm 0,04$ & $0,86 \pm 0,04$ \\
\hline Лейкоцити, 10\%/л & $10,30 \pm 0,40$ & $12,50 \pm 0,50^{1}$ & $12,80 \pm 0,50^{1}$ & $12,20 \pm 0,40^{1}$ \\
\hline Нейтросріли юні, \% & 0 & 0 & 0 & 0 \\
\hline Нейтрофріли паличкоядерні, \% & $0,80 \pm 0,20$ & $7,20 \pm 0,40^{1}$ & $7,60 \pm 0,50^{1}$ & $7,30 \pm 0,40^{1}$ \\
\hline Нейтрофріли сегментоядерні, \% & $22,70 \pm 0,80$ & $31,50 \pm 1,10^{1}$ & $32,50 \pm 1,10^{1}$ & $30,10 \pm 0,90^{1}$ \\
\hline Еозиносріли, \% & $1,10 \pm 0,20$ & $0,80 \pm 0,20$ & $1,00 \pm 0,30$ & $1,20 \pm 0,30$ \\
\hline Базофріли, \% & $0,70 \pm 0,20$ & $0,30 \pm 0,20$ & $0,50 \pm 0,30$ & $0,80 \pm 0,20$ \\
\hline Моноцити, \% & $3,00 \pm 0,50$ & $3,30 \pm 0,20$ & $3,50 \pm 0,40$ & $3,20 \pm 0,30$ \\
\hline Лімсооцити, \% & $71,70 \pm 1,00$ & $56,90 \pm 1,50^{1}$ & $55,00 \pm 1,00^{1}$ & $57,40 \pm 1,00^{1}$ \\
\hline ШОЕ, мм/год & $4,20 \pm 0,50$ & $8,80 \pm 0,60^{1}$ & $9,20 \pm 0,50^{1}$ & $8,30 \pm 0,70^{1}$ \\
\hline \multicolumn{5}{|c|}{ 25-та доба дослідження } \\
\hline Гемоглобін, г/л & $129,00 \pm 6,00$ & $130,00 \pm 6,00$ & $127,00 \pm 5,90$ & $128,10 \pm 5,90$ \\
\hline Еритроцити, $10^{12} / л$ & $4,48 \pm 0,20$ & $4,68 \pm 0,21$ & $4,43 \pm 0,20$ & $4,49 \pm 0,20$ \\
\hline КП & $0,87 \pm 0,04$ & $0,84 \pm 0,04$ & $0,86 \pm 0,04$ & $0,86 \pm 0,04$ \\
\hline Лейкоцити, 10\%/л & $10,10 \pm 0,40$ & $11,90 \pm 0,40^{1}$ & $10,50 \pm 0,40^{2,3}$ & $10,70 \pm 0,40^{3}$ \\
\hline Нейтросріли юні, \% & 0 & 0 & 0 & 0 \\
\hline Нейтрофріли паличкоядерні, \% & $1,00 \pm 0,30$ & $5,90 \pm 0,20^{1}$ & $1,80 \pm 0,30^{2,3}$ & $2,00 \pm 0,40^{2,3}$ \\
\hline Нейтрофріли сегментоядерні, \% & $23,30 \pm 0,80$ & $29,60 \pm 1,00^{1}$ & $24,60 \pm 0,90^{2,3}$ & $26,00 \pm 0,90^{2,3}$ \\
\hline Еозиносріли, \% & $1,30 \pm 0,20$ & $1,10 \pm 0,30$ & $1,30 \pm 0,30$ & $1,00 \pm 0,40$ \\
\hline Базофріли, \% & $0,80 \pm 0,20$ & $0,60 \pm 0,20$ & $1,00 \pm 0,30$ & $0,80 \pm 0,30$ \\
\hline Моноцити, \% & $2,60 \pm 0,20$ & $2,90 \pm 0,30$ & $3,20 \pm 0,20$ & $3,00 \pm 0,40$ \\
\hline Лімфоцити, \% & $71,00 \pm 0,80$ & $59,90 \pm 1,20^{1}$ & $68,00 \pm 0,90^{2,3}$ & $67,20 \pm 1,40^{2,3}$ \\
\hline ШОЕ, мм/год & $4,00 \pm 0,40$ & $9,50 \pm 0,50^{1}$ & $5,00 \pm 0,50^{2,3}$ & $5,50 \pm 0,40^{1,2,3}$ \\
\hline
\end{tabular}

Примітки:

1. *n - загальна кількість експериментальних тварин; **n - кількість експериментальних тварин у кожній групі.

2. ${ }^{1}$ - достовірно відносно групи інтактного контролю $(p<0,05) ;{ }^{2}-$ достовірно відносно групи контрольної патології $(p<0,05) ;{ }^{3}$ - достовірно відносно стану тварин цієї групи на 15 -ту добу дослідження $(p<0,05)$.

перебіг патології та купірувати осередок запалення в порожнині носа.

При пероральному застосуванні у кролів 3 ЕРС препарату порівняння BNO-101 спостерігали аналогічний характер дії, але дещо менший (недостовірно) за ступенем впливу. Так, рівень лейкоцитів у крові зменшувався до $10,7 \times 10 \%$ л, вміст паличкоядерних нейтрофрілів - до 2,0 \%, сегментоядерних - до $26,0 \%$, а лімсроцитів збільшувався до 67,2 \%. Показник ШОЕ знижувався до 5,5 мм/год, але при цьому не досягав інтактного рівня, на відміну від дії ЕнЙ.

Клінічне дослідження. У цьому клінічному дослідженні було зареєстровано 36 випадків виникнення ПР у 22-х добровольців: 25 випадків ПР $(69,4$ \%) - присмак після введення ЕнЙ/ плацебо; 11 випадків ПР (30,6 \%) - дискомфорт у порожнині носа після введення ЕнЙ/плацебо.

Усі випадки ПР належать до локальної переносимості. Усі вони були легкого ступеня тяжкості, несерйозними, передбаченими, не вимагали терапії, результат - одужання без залишкових явищ, зв'язок із прийманням длз/ плацебо - ймовірний у 25-ти випадках і певний в 11-ти випадках.
Після введення длз було зареєстровано 23 випадки (92 \%) ПР (присмак), після введення плацебо - 2 випадки (8 \%).

Після введення ДЛЗ було зареєстровано 6 випадків (54,5 \%) ПР (дискомсрорт у порожнині носа), після введення плацебо - 5 випадків (45,5\%).

Аналіз результатів статистичної обробки даних локальної переносимості (результати риноскопії, присмак, відчуття дискомсоорту, чхання) та безпеки (ПР, дані фрізикального огляду, результати лабораторно-інструментального обстеження) в ходіпроведенняцьогодослідження свідчить про те, що:

- ДЛЗнепоступаєтьсяплацебо запоказником “локальна переносимість", а всі встановлені відмінності є статистично незначущими;

- ДЛЗ непоступаєтьсяплацебозапоказником "безпека", а всі встановлені відмінності є статистично незначущими.

ВИСНОВКИ. Отримані результати доклінічного дослідження свідчать про те, що на тлі експериментального риносинуситу в кролів Енісаміум Йодид при інтраназальному засто- 
суванні чинить позитивний вплив на перебіг патології за даними лабораторних спостережень та гематологічних аналізів. До того ж, за рівнем активності він не поступається пероральному препарату порівняння BNO-101 - відомому засобу лікування риносинуситу, який включено до клінічних гайдлайнів та протоколів. Аналіз статистичних даних клінічного дослідження свідчить про добру локальну переносимість та безпеку використання Енісаміуму Йодиду (назального спрею) 10 мг/мл при різних режимах дозування.

Перспективи подальших досліджень. 3 огляду на виявлені особливості фрармакоди- намічного профрілю, Енісаміум Йодид (назальний спрей) 10 мг/мл доцільно розглядати як препарат, перспективний для подальших досліджень, метою яких $є$ поглиблене вивчення його ефективності та безпеки. Результати цих досліджень дозволять обґрунтувати призначення Енісаміуму Йодиду для лікування гострого риносинуситу та імплементацію його в клінічну практику у вигляді топічного лікарського засобу для патогенетичної терапії. Це підвищить не тільки ефективність, але й безпеку лікування даної патології в різних груп пацієнтів, зокрема хворих з коморбідною патологією.

\section{СПИСОК ЛІТЕРАТУРИ}

1. Kwah J. H. Nasal polyps and rhinosinusitis / J. H. Kwah, A. T. Peters // Allergy Asthma Proc. - 2019. 40 (6). - P. 380-384. Access mode : http://doi: 10.2500/ aap.2019.40.4252

2. De Boer D. L. Acute sinusitis / D. L. De Boer, E. Kwon. - StatPearls. Treasure Island (FL): StatPearls Publishing, 2019.

3. European position paper on rhinosinusitis and nasal polyps 2020 / W. J. Fokkens, V. J. Lund, C. Hopkins [et al.] // Rhinology. -2020. -58 (SUPPL. 29). - P. 1-481.

4. Уніфікований клінічний протокол первинної, вторинної (спеціалізованої) та третинної (високоспеціалізованої) медичної допомоги: гострий риносинусит // Наказ Міністерства охорони здоров'я України від 11 лютого 2016 р. № 85. - С. 17-24.

5. Жулай Т. С. Дослідження дозозалежності антиексудативної дії нового назального спрею 3 протизапальними властивостями / Т. С. Жулай, І. А. Зупанець, С. К. Шебеко // Клініч. фрармація. 2017. - 21 (4). - C. 11-17.

6. Zhulai T. S. Preclinical study of a new nasal spray with anti-inflammatory properties: the effect on the leukotriene-induced inflammation / T. S. Zhulai // Clinical pharmacy. - 2018. - 22 (4). - P. 27-33.

7. Zhulai T. Perspectives for use of the new nasal spray with anti-inflammatory action in treatment of acute rhinosinusitis / T. Zhulai, S. Shebeko, A. Goy // Rhinology. - 2018. - 56 (27). - P. 585.

8. Порядок проведення клінічних випробувань лікарських засобів та експертизи матеріалів клінічних випробувань і Типове положення про комісії з питань етики : наказ Міністерства охорони здоров'я України від 23.09.2009 р. № 690 зі змінами [Електронний ресурс]. - Режим доступу : http://zakon1.rada.gov.ua/ laws/show/z1010-09).

9. Лікарські засоби. Належна клінічна практика : настанова СТ-Н МОЗУ 42-7.0:2008. - К., 2009. - 48 с.

10. Пат. на корисну модель 54725 Україна, МПК (2009) А 61 В 5/00. Спосіб визначення переносимості лікарських засобів при проведенні першої фрази клінічних досліджень тадослідженні біоеквівалентності / Доброва В. Є., Зупанець І. А., Шаламай А. С.,
Старченко М. Г. ; заявник та патентовласник Нац. фармац. ун-т. - № u 201004542 ; заявл. 19.04.10 ; опубл. 25.11.10, Бюл. № 22.

11. ICH E6: Good Clinical Practice: Consolidated guideline. CPMP/ICH/135/95.

12. Chow S. C. Sample size calculations in clinical research / S. C. Chow, J. Shao, H. Wang. - London : Taylor\&Francis, 2003. $-358 \mathrm{p}$.

13. Directive 2001/20/EC of the European Parliament and of the Council of 4 April 2001 on the approximation of the laws, regulations and administrative provisions of the Member States relating to the implementation of good clinical practice in the conduct of clinical trials on medicinal products for human use // Official Journal of the European Communities. L 121, 1.5.2001.

14. Guideline on strategies to identify and mitigate risks for first-inhuman clinical trials with Investigational Medicinal Products. EMEA/CHMP/SWP/28367/07.

15. A safety grading scale to support dose escalation and define stopping rules for healthy subject first-entryinto-man studies / M. Sibille, A. Patat, H. Caplain, Y. Donazzolo // British Journal of Clinical Pharmacology. 2010. - 70 (50). - P. 736-748.

16. Guidance for Industry Estimating the Maximum Safe Starting Dose in Initial Clinical Trials for Therapeutics in Adult Healthy Volunteers. FDA/CDER, July 2005.

17. Про державну реєстрацію (перереєстрацію) лікарських засобів (медичних імунобіологічних препаратів) та внесення змін до реєстраційних матеріалів : наказ МОЗ України від 12 травня 2017 р. № 509 [Електронний ресурс]. - Режим доступу : http://search. ligazakon.ua/__doc2.nsf/link1/MOZ27507.html.

18. Parliament, European \& Council, European. DIRECTIVE 2010/63/EU on the protection of animals used for scientific purposes. EU Official Journal. - 2010. L276.

19. Guidance for industry. Estimating the Maximum Safe Starting Dose in Initial Clinical Trials for Therapeutics in Adult Healthy Volunteers. FDA - 2005. - P. 1-30.

20. Administration of substances to laboratory animals: Equipment considerations, vehicle selection, and solute preparation / P. V. Turner, C. Pekow, 
M. A. Vasbinder, T. Brabb // Journal of the American Association for Laboratory Animal Science. - 2001. 50 (5). - P. 614-627.

21. Flecknell P. A. Laboratory animal anesthesia / P. A. Flecknell. $4^{\text {th }}$ ed. Oxford: Academic Press, 2015. P. 1-350. http://dx.doi.org/10.1016/C2013-0-13494-0

22. Review of experimental models: sinusitis in rabbits / A. C. Pereza, G. P. Buzattob, I. de Picole Dantasb, J. Vicente // Braz. J. Otorhinolaryngol. - 2014. - 80 (5) . P. 435-440. Access mode : http://dx.doi.org/10.1016/j. bjorl.2014.07.011

23. Comparative study of several sinusitis experimental modelling techniques in rabbits / $\mathrm{H}$. O. Costa, G. E. Ruschi e Luchi, A. G. Augusto [et al.] // Rev. Bras. Otorrinolaringol. - 2007. - 73 (5). - P. 627-631. Access mode: $h$ ttp://dx.doi.org/10.1590/S0034-72992007000500007

24. Is nasal endoscopy of diagnostic value in chronic rhinosinusitis without nasal polyps? / R. Cohen-Kerem, T. Marshak, N. Uri [et al.] // Ear, Nose Throat J. - 2019. P. 1-5. Access mode: http://doi.org/10.1177/ 0145561319864578

25. Nasal endoscopy is recommended for diagnosing adults with chronic rhinosinusitis / A. M. Wuister, N. A. Goto, E. J. Oostveen [et al.] // Otolaryngol. Head Neck Surg. - 2014. - 150 (3). - P. 359-364. Access mode : https://doi.org/10.1177/0194599813514510

26. Impact of educational intervention on the interrater agreement of nasal endoscopy interpretation / P. Colley, J. C. Mace, M. R. Schaberg [et al.] // Laryngoscope. - 2015. - 125 (10). - P. 2259-2265. https://doi.org/10.1002/lary.25240

27. Клиническая лабораторная диагностика : нац рук. : в 2 т. Т. 1. / под ред. В. В. Долгова, В. В. Меньшикова. - М. : ГЭОТАР-Медиа, 2012. - 928 с.
28. Медицинские лабораторные технологии : справочник : в 2 т. Т. 1 / под ред. А. И. Карпищенко. СПб. : Интермедика, 2002. - 408 с. ; Т. 2 / под ред. А. И. Карпищенко. - СПб. : Интермедика, 2002. -600 с.

29. Методы клинических лабораторных исследований / под ред. В. С. Камышникова. -4-е изд. - М. : МЕДпресс-инсоорм, 2011. - 752 с.

30. OECD Series on Principles of Good Laboratory Practice and Compliance Monitoring No 20. Guidance Document for Receiving Authorities on the Review of the GLP Status of NonClinical Safety Studies. ENV/JM/ MONO 2019. 25 p.

31. Directive 2001/20/EC of the European Parliament and of the Council of 4 April 2001 on the approximation of the laws, regulations and administrative provisions of the Member States relating to the implementation of good clinical practice in the conduct of clinical trials on medicinal products for human use. Official Journal of the European Communities. L 121, 1.5.2001.

32. Guideline on strategies to identify and mitigate risks for first-inhuman clinical trials with Investigational Medicinal Products. EMEA/CHMP/SWP/28367/07.

33. Islam M. A. Foundations of Biostatistics / M. A. Islam, A. Al-Shiha. Springer Nature Singapore Ltd, 2018.

34. Quirk T. J. Excel 2016 for Biological and Life Sciences Statistics: A Guide to Solving Practical Problems / T. J. Quirk, M. H. Quirk, H. F. Horton // Springer International Publishing Switzerland, 2016.

35. Наукове обґрунтування методології статистичної оцінки переносимості лікарських засобів при проведенні клінічних випробувань : метод. рек. I В. Є. Доброва, І. А. Зупанець, А. М. Морозов [та ін.]. Х. : ФОП Петров В. В., 2012. - 36 с.

\section{REFERENCES}

1. Kwah, J.H., \& Peters, A.T. (2019). Nasal polyps and rhinosinusitis. Allergy Asthma Proc., 40 (6), 380384. Retrieved from: http://doi: 10.2500/aap. 2019.40.4252

2. De Boer, D.L., \& Kwon, E. (2019). Acute sinusitis. StatPearls. Treasure Island (FL): StatPearls Publishing.

3. Fokkens, W.J., Lund, V.J., Hopkins, C., Hellings, P.W., Kern, R., Reitsma, S. ..., \& Zwetsloot, C.P. (2020). European position paper on rhinosinusitis and nasal polyps 2020. Rhinology, 58 (29), 1-481.

4. (2016). Ministerstvo okhorony zdorovia Ukrainy. Unifikovanyi klinichnyi protokol pervynnoi, vtorynnoi (spetsializovanoi) ta tretynnoi (vysokospetsializovanoi) medychnoi dopomohy: hostryi rynosynusyt. Nakaz Ministerstva okhorony zdorovia Ukrainy [Ministry of Health of Ukraine. Unified clinical protocol for primary, secondary (specialized) and tertiary (highly specialized) care: acute rhinosinusitis. Order of the Ministry of Health of Ukraine]. No. 85, 17-24 [in Ukrainian].

5. Zhulai, T.S., Zupanets, I.A., \& Shebeko, S.K. (2017). Doslidzhennia dozozalezhnosti antyeksudatyvnoi dii novoho nazalnoho spreiu z protyzapalnymy vlasty- vostiamy [Investigation of dose dependence of anti-exudative action of a new nasal spray with anti-inflammatory properties]. Klinichna farmatsiya - Clinical Pharmacy, 21 (4), 11-17. Retrieved from: http://doi.org/10.24959/ cphj.17.1446 [in Ukrainian].

6. Zhulai, T.S. (2018). Preclinical study of a new nasal spray with anti-inflammatory properties: the effect on the leukotriene-induced inflammation. Klinichna farmatsiia Clinical Pharmacy, 22 (4), 27-33. Retrieved from: http:// doi.org/10.24959/cphj.18.1473 [in Ukrainian].

7. Zhulai, T., Shebeko, S., \& Goy, A. (2018). Perspectives for use of the new nasal spray with antiinflammatory action in treatment of acute rhinosinusitis. Rhinology, 56 (27), 585. Retrieved from: https://www. rhinologyjournal.com

8. Poriadok provedennia klinichnykh vyprobuvan likarskykh zasobiv ta ekspertyzy materialiv klinichnykh vyprobuvan i typove polozhennia pro komisii z pytan etyky (zatverdzheno Nakazom Ministerstva okhorony zdorovia Ukrainy vid 23.09.2009 h. № 690 zi zminamy [Procedure for conducting clinical trials of medicinal products and examination of clinical trial materials and Model 
Regulations on Ethics Committees (approved by Order of the Ministry of Health of Ukraine dated 23.09.2009 № 690 as amended)]. Retrieved from: http://zakon1.rada. gov.ua/laws/show/z1010-09.

9. (2009). Nastanova ST-N MOZU 42-7.0:2008 "Likarski zasoby. Nalezhna klinichna praktyka" [Guideline of the Ministry of Health of Ukraine 42-7.0: 2008 "Medicines. Good clinical practice"]. Kyiv [in Ukrainian].

10. Dobrova, V.le., Zupanets, I.A., Shalamai, A.S., \& Starchenko, M.H. (2010). Pat. 54725 Ukrainy na korysnu model, MPK (2009) A 61 V 5/00. Sposib vyznachennia perenosymosti likarskykh zasobiv pry provedenni pershoi fazy klinichnykh doslidzhen ta doslidzhenni bioekvivalentnosti [Pat. 54725 Ukraine for utility model, IPC (2009) A 61 B 5/00. The method of determining the tolerability of drugs during the first phase of clinical trials and bioequivalence studies]. zaiavnyk ta patentovlasnyk Natsionalnyi farmatsevtychnyi universytet. - №u 2010 04542; zaiavl. 19.04.10; opubl. 25.11.10, Biul. № 22 [in Ukrainian].

11. ICH E6: Good Clinical Practice: Consolidated guideline. CPMP/ICH/135/95

12. Chow, S.C., Shao, J., \& Wang, H. (2003). Sample size calculations in clinical research. London: Taylor\& Francis.

13. Directive 2001/20/EC of the European Parliament and of the Council of 4 April 2001 on the approximation of the laws, regulations and administrative provisions of the Member States relating to the implementation of good clinical practice in the conduct of clinical trials on medicinal products for human use. L 121, 1.5.2001

14. Guideline on strategies to identify and mitigate risks for first-inhuman clinical trials with Investigational Medicinal Products. EMEA/CHMP/SWP/28367/07.

15. Sibille, M., Patat, A., Caplain, H., \& Donazzolo, Y. (2010). A safety grading scale to support dose escalation and define stopping rules for healthy subject first-entryinto-man studies. British Journal of Clinical Pharmacology, $70,5,736-748$.

16. (2005). Guidance for Industry Estimating the Maximum Safe Starting Dose in Initial Clinical Trials for Therapeutics in Adult Healthy Volunteers. FDA/CDER.

17. Ministerstvo okhorony zdorovia Ukrainy, Nakaz № 509 vid 12 travnia, 2017. Pro derzhavnu reiestratsiiu (perereiestratsiiu) likarskykh zasobiv (medychnykh imunobiolohichnykh preparativ) ta vnesennia zmin do reiestratsiinykh materialiv [Ministry of Health of Ukraine, Order No. 509 of May 12, 2017. On state registration (re-registration) of medicinal products (medical immunobiological preparations) and amendments to registration materials]. Retrieved from: http://search.ligazakon.ua/l doc2.nsf/link1/MOZ27507.html [in Ukrainian].

18. Parliament, European \& Council, European. (2010). DIRECTIVE 2010/63/EU on the protection of animals used for scientific purposes. EU Official Journal. L276.

19. Guidance for industry. (2005). Estimating the Maximum Safe Starting Dose in Initial Clinical Trials for Therapeutics in Adult Healthy Volunteers. FDA, 1-30.

20. Turner, P.V., Pekow, C., Vasbinder, M.A., \& Brabb, T. (2001). Administration of substances to laboratory animals: Equipment considerations, vehicle selection, and solute preparation. Journal of the American Association for Laboratory Animal Science, 50 (5), 614-627.
21. Flecknell, P.A. (2015). Laboratory Animal Anesthesia, $4^{\text {th }}$ ed. Oxford: Academic Press, 1-350. Retrieved from: http://dx.doi.org/10.1016/C2013-0-13494-0

22. Pereza, A.C, Buzattob G.P, de Picole Dantasb, I., \& Vicente, J. (2014). Review of experimental models: sinusitis in rabbits. Braz. J. Otorhinolaryngol., 80 (5), 435-440. Retrieved from: http://dx.doi.org/10.1016/j. bjorl.2014.07.011

23. Costa, H.O., Ruschi e Luchi, G.E., Augusto, A.G., Castro, M., \& Coelho de Souza, F. (2007). Comparative study of several sinusitis experimental modelling techniques in rabbits. Rev. Bras. Otorrinolaringol., 73 (5), 627-631. Retrieved from: http://dx.doi.org/10.1590/ S0034-72992007000500007

24. Cohen-Kerem, R., Marshak, T., Uri, N., Gruber, M., Huberfeld O., Paz D., ... Ronen, O. (2019). Is nasal endoscopy of diagnostic value in chronic rhinosinusitis without nasal polyps? Ear, Nose Throat J., 1-5. Retrieved from: http://doi.org/10.1177/0145561319864578

25. Wuister, A.M., Goto, N.A., Oostveen, E.J., de Jong, W.U., van der Valk, E.S., Kaper, N.M., ..., \& van der Heijden, G.J.M.G. (2014). Nasal endoscopy is recommended for diagnosing adults with chronic rhinosinusitis. Otolaryngol Head Neck Surg., 150 (3), 359-364. Retrieved from: https://doi.org/10.1177/ 0194599813514510

26. Colley, P., Mace, J.C., Schaberg, M.R., Smith, T.L., \& Tabaee, A. (2015). Impact of educational intervention on the interrater agreement of nasal endoscopy interpretation. Laryngoscope, 125 (10), 2259-2265. Retrieved from: https://doi.org/10.1002/lary.25240

27. Dolgov, V.V., \& Menshikov, V.V. (Ed.) (2012). Klinicheskaya laboratornaya diagnostika: naczionalnoe rukovodstvo [Clinical laboratory diagnostics: national leadership]. Moscow: GEOTAR-Media [in Russian].

28. Karpishhenko, A.I. (Ed.) (2002). Meditsinskie laboratornye tekhnologii: Spravochnik [Medical laboratory technology: Reference]. Saint-Petersburg: Intermedika [in Russian].

29. Kamyshnikov, V.S. (Ed.). (2011). Metody klinicheskikh laboratornykh issledovanii [Methods of clinical laboratory research]. 4-e izd. Moscow: MEDpress-inform [in Russian].

30. OECD Series on Principles of Good Laboratory Practice and Compliance Monitoring No 20. (2019). Guidance Document for Receiving Authorities on the Review of the GLP Status of NonClinical Safety Studies. ENV/JM/MONO, 25.

31. Directive 2001/20/EC of the European Parliament and of the Council of 4 April 2001 on the approximation of the laws, regulations and administrative provisions of the Member States relating to the implementation of good clinical practice in the conduct of clinical trials on medicinal products for human use. Official Journal of the European Communities, L 121, 1.5.2001

32. Guideline on strategies to identify and mitigate risks for first-inhuman clinical trials with Investigational Medicinal Products. EMEA/CHMP/SWP/28367/07.

33. Islam, M.A., \& Al-Shiha, A. (2018). Foundations of Biostatistics. Springer Nature Singapore Ltd.

34. Quirk, T.J., Quirk, M.H., \& Horton, H.F. (2016). Excel 2016 for Biological and Life Sciences Statistics: A Guide to Solving Practical Problems. Springer International Publishing Switzerland. 
35. Dobrova, V.Ye., Zupanecz, I.A., Morozov, A.M., Nikolayeva, V.V., Bezugla, N.P., \& Starchenko, M.G. (2012). Naukove obhruntuvannia metodolohii statistychnoi oczinky perenosymosti likarskykh zasobiv pry provedenni klinichnykh vyprobuvan: metod. rek. [On the science of methodology of statistical estimation of tolerability of drug problems during clinical trials: guidelines]. Kharkiv: FOP Petrov V. V. [in Ukrainian].

\author{
Т. С. Жулай ${ }^{1,2}$, И. А. Зупанец ${ }^{1}$, С. К. Шебеко ${ }^{1}$, Н. П. Безуглая ${ }^{1}$, С. М. Зимин ${ }^{1}$ \\ НАЦИОНАЛЬНЫЙ ФАРМАЦЕВТИЧЕСКИЙ УНИВЕРСИТЕТ ${ }^{1}$, ХАРЬКОВ

\title{
ЭФФЕКТИВНОСТЬ И ПЕРЕНОСИМОСТЬ ЭНИСАМИУМА ЙОДИДА НАЗАЛЬНОГО СПРЕЯ: РЕЗУЛЬТАТЫ ДОКЛИНИЧЕСКИХ И КЛИНИЧЕСКИХ ИССЛЕДОВАНИЙ
}

\section{Резюме}

Вступление. Существуют различия в подходах к лечению острого риносинусита в зависимости от его ведущих клинических симптомов, в частности назальной обструкции и лицевой боли. На АО “Фармак" (Украина) было разработано новый назальный спрей с водным раствором Энисамиума Йодида (ЭнЙ) оригинальную лекарственную форму известного фрармацевтического вещества.

Цель исследования - определить эфрфективность Энисамиума Йодида при лечении острого риносинусита и его переносимость/безопасность.

Методы исследования. Объектом исследования стал Энй (назальный спрей) 10 мг/мл. В качестве референтного препарата в экспериментальной части работы был использован BNO-101 под торговым названием "Sinupret@”. Экспериментальный риносинусит воспроизведен на24-хкролях (4 экспериментальные группы по 6 кроликов в каждой) в 1-й день исследования. С 15-х суток животные получали в течение 10-ти суток препараты: 0,9% фризиологический раствор (0,1 мл интраназально) - в группах интактного контроля и контрольной патологии (1-й и 2-й группах соответственно), Энй (назальный спрей) 10 мг/мл (0,1 мл интраназально) - в 3-й группе и BNO-101 (25 мг/мл интрагастрально) - в 4-й группе. Оценивали результаты лечения на 25-е сутки (лабораторное наблюдение, результаты анализа перифрерической крови). Клиническую часть работы проведено в виде одноцентрового, рандомизированного, двойного слепого, плацебо-контролируемого клинического исследования с эскалацией дозы - изучения локальной переносимости и безопасности (I фраза) различных доз нового лекарственного препарата Энй (назального спрея) 10 мг/мл с участием здоровых добровольцев.

Результаты и обсуждение. На фроне развития экспериментального риносинусита за счет местного действия Энй (назальный спрей) достоверно положительно влиял на течение патологии. Анализ статистических данных локальной переносимости свидетельствует о том, что он не уступал плацебо по показателям “локальная переносимость" и “безопасность", а все установленные различия были статистически не значимы.

Выводы. Полученные результаты доклинического исследования показали, что Энисамиум Йодид, по данным лабораторных наблюдений и гематологических анализов, оказывает положительное влияние на течение экспериментального риносинусита и при этом по уровню активности не уступает препарату сравнения BNO-101. Анализ статистических данных клинического исследования свидетельствует о хорошей переносимости/безопасности Энисамиума Йодида (назального спрея) 10 мг/мл.

КЛЮЧЕВЫЕ СЛОВА: экспериментальный риносинусит; Энисамиум Йодид (назальный спрей); клиническое исследование; переносимость; безопасность. 


\section{EFFECTIVENESS AND TOLERANCE OF ENISAMIUM IODIDE NASAL SPRAY: PRE-CLINICAL STUDY AND CLINICAL TRIAL RESULTS}

\section{Summary}

Introduction. There are differences in acute rhinosinusitis (ARS) treatment approaches depending on the leading clinical symptoms, in particular, nasal obstruction and facial pain. Farmak JSC (Ukraine) has developed a new nasal spray with Enisamium lodide (EI) aqueous solution - original dosage form of a well-known pharmaceutical substance.

The aim of the study - to substantiate the effectiveness of EI (nasal spray) in the treatment of certain pathology and tolerance/safety of its use.

Researsch Methods. El (nasal spray) $10 \mathrm{mg} / \mathrm{mL}$ was the study subject. BNO-101 under the trade name Sinupret ${ }^{\circledR}$ was used as a reference drug in the experimental part of the study. Experimental rhinosinusitis (ERS) was induced in 24 rabbits (4 groups, 6 rabbits in each group) on the first experimental day. Since 15th day, the animals received the drugs for 10 days: $0.9 \%$ saline at $0.1 \mathrm{ml}$ intranasally in the intact control and control pathology group, El (nasal spray) at $0.1 \mathrm{ml}$ intranasally in the $3 \mathrm{rd}$ group and BNO-101 at $25 \mathrm{mg} / \mathrm{mL}$ intragastrally in the 4th group. Treatment results were evaluated on the 25th day (laboratory observation, peripheral blood analysis results). The clinical part of the work has been conducted as a single-centre, randomized, double-blinded, placebo-controlled clinical trial with dose escalation - study of local tolerance and safety (Phase I) of different doses of the new drug El (nasal spray) $10 \mathrm{mg} / \mathrm{mL}$ with healthy volunteers.

Results and Discussion. The results indicate that El (nasal spray) is able to positively influence on ERS significantly due to local action. Statistical data analysis of local tolerance indicates that El is not inferior to placebo in indicators of "local tolerance" and "safety", and all differences are statistically insignificant.

Conclusions. The preclinical study results indicate that Enisamium iodide under the laboratory observations and hematological analyzes has a positive effect on ERS, and in activity is not inferior to BNO-101 as comparison drug. Statistical data analysis of clinical trial indicates good tolerance/safety of Enisamium lodide (nasal spray) 10 $\mathrm{mg} / \mathrm{mL}$.

KEY WORDS: experimental rhinosinusitis; Enisamium lodide (nasal spray); portability; safety.

Адреса для листування: Т. С. Жулай, Національний фрармацевтичний університет, вул. Пушкінська, 53, Харків, 61002, Україна, e-mail: tszhulay2910@gmail.com. 